\title{
河川魚類の個体数に影響を及ぼす多様な環境要 因の相対的重要度の評価：繁殖時期に着目して EVALUATION OF RELATIVE IMPORTANCE OF VARIOUS ENVIRONMENTAL FACTORS INFLUENCING POPULATION VARIABILITY OF RIVERINE FISHES BASED ON REPRODUCTION TIMINGS
}

\author{
梁 政寛 1 ・吉村 千洋 2 ・岩崎 雄一 3 \\ Masahiro RYO, Chihiro YOSHIMURA and Yuichi IWASAKI
}

1正会員 工博 東京工業大学研究員 土木工学専攻（†152-0033 東京都目黒区大岡山2-12-1-M1-4）
2正会員 工博 東京工業大学准教授 土木工学専攻（†152-0033 東京都目黒区大岡山2-12-1-M1-4）
3非会員 環博 東洋大学研究助手 生命環境科学研究センター（†374-0193 群馬県邑楽郡板倉町泉野1-

1-1)

We evaluated the relative importance of flow regimes, water temperature, and water quality influencing on the inter-annual population variability of 20 fish species (1993-99) in the Sagami River, Japan, using a random forests approach. A result indicated that flow regime conditions before and after spawning season (April-August and October-December, respectively) and temperature after spawning season influence the population variability of many species most dominantly (relative importance $>15 \%$ for 10,8 , and 5 species, respectively). Hence, to mimic the natural variability of these factors particularly in the suggested seasons may contribute to better sustain the ecological healthiness in the Sagami River.

Key Words : Flow regime, Random forests, Data mining, Non-linearity, Conservation, Ecosystem

\section{1.はじめに}

河川を含む淡水生物の個体数は過去わずか40年で $76 \%$ 減少し，陸域や海域における減少 $(40 \%)$ よ りも一層深刻であることが推定されており ${ }^{1)}$ ，その 保全対策は喫緊かつ重要な課題である。定性的な環 境評価に加えて，これまでに数多くの定量的な環境 一生態応答モデルが開発され，実河川への適用が試 みられてきた。著名なものとしてWeighted Usable Areaに基づくPhysical Habitat Simulation (PHABSIM) やHabitat Suitability Indexに基づく在不在ポテンシャ ルの評価などがある ${ }^{2)}$ 。これらは高い汎用性を持ち, 比較的簡便に定量的な環境影響評価が可能なモデル である。しかし, 狭い少数の生息場にしか適用でき ない事や，一部の環境要因が変化した際に既存の経 験式が適用できなくなるなどの報告も多く，このよ うな適用限界も明らかになるにつれて, 生態学的な 過程に基づく（Process-based）モデルの開発へと研 究の潮流はシフトしつつある ${ }^{3)}$.

環境変化に対する生物応答のプロセスをモデル化 するためには, その生活史戦略や，行動様式（摂食,
産卵，移動など）といった点にまで考慮する必要が ある。しかし，実際の河川において環境の変化が動 物の行動に及ぼす影響（例えば，洪水中の回避行 動）はあまり定量化されておらず, さらに種によっ ても応答は異なるため ${ }^{4)}$, プロセスベースの生態モ デル構築のための知見が不足している。従って, 個々の生態学的なプロセスに着目した際の, 環境要 因と生物応答の関係を定量化する試みが必要であり, 様々な環境要因が異なる種や行動に対して及ぼす相 対的な影響度の評価もプロセス型モデル化に向けて 有益な知見となる。

従来の在不在や生息場の好適性評価では表現でき ない生物応答の特徵として, 個体数の変動が挙げら れる。例え在不在解析によって，ある種が生息する と推定された場合でも, 個体数は定量的に推定でき ない. また，現在生息するとしても長期的に個体数 が減少傾向にあるならば，保全対策は必要となるだ ろう。従って，個体数変動に関わるプロセスに着目 した際の, 環境要因と個体数変動の関係性評価をす ることで, 個体群動態を考慮した河川生態系の保全 
手法が見えてくる.また, 個体数変動の主要因であ る繁殖行動は, 多くの河川生物は強い季節的な周期 性を持ち, 産卵時期の知見は比較的蓄積されている 5). そのため, 産卵期やその前後の時期に着目した 環境条件と繁殖行動は関連性を評価しやすい（例え ば産卵期の水温とふ化率の関係など）。

また, 河川管理上欠かせない解析対象の環境要因 として，流況がある. 流況（平時流量のみならず， 渇水や洪水を含めた流量の変動特性） は他の環境要 因を動的に変動させることを介して, 生態系の構造 や機能を維持, 駆動する主要因の一つである ${ }^{6)}$. 近 年, 水力発電や取水などの水資源利用により引き起 こされる流況の改変が世界的にも深刻な問題となっ ており, 流況改変が生態系に及ぼす影響を軽減する 試み（人工洪水など）の重要性は河川管理において 認知されつつある。事実, 流量は他の環境要因（地 形状, 水質, 水温, 水理条件など）に比べても定量 的かつ精確に管理・操作を行いやすい. 従って, 流 況が生物に及ぼす影響を理解することは, 河川生態 系の適切な管理・保全に役立つ ${ }^{7)}$.

上記の背景を踏まえ, 本研究では, 神奈川県相模 川下流平野部（総延長 $45 \mathrm{~km}$ ) の魚類を対象として, 産卵期とその前後の時期における主要な環境要因

（流況・水温・水質）を用いて，複数年（1993，94, 97, 99年）にまたがる魚類種（代表20種）の個体数 の増減傾向の解析を行った. 環境要因は, 魚類調査 年およびその前年を考慮し, 地形や魚類採捕調査時 における調査方法も説明要因に含めた。これら環境 要因の相対的重要度を評価するため, 最新の機械学 習法の一つであるランダム・フォレストを適用した。

\section{2. 方法}

\section{（1）対象河川}

a) 地理・地形状・構造物

山梨県・神奈川県を跨ぐ相模川水系相模川の平野 部を対象とした（図-1）. 集水面積は $1680 \mathrm{~km}^{2}$, 全 長 $109 \mathrm{~km}$ の一級河川である。流域の山岳部は森林で, 平野部は都市が支配的である。雨季は主に6月から 10月で，時に台風や梅雨による強い豪雨を伴う．

流域のなかでも研究対象区域となる平野部河川の 構造として, 本流の相模川と支流の中津川がある

（図-1）. 共にダムによる河川の分断化（相模川は 城山ダム, 中津川は宮が瀬ダム）が生じており，ま た河口は湾へと流れ込む. なお，対象区域において 河口から本流および支流の上端（すなわちダム）ま での距離は共に約33 kmであり, 本流と支流の合流 点は河口から $15 \mathrm{~km}$ である. 取水堰などの河川横断 構造物は複数あるが, それら全ては魚道を備えるな どして，魚類の上下の往来に配慮している ${ }^{8)}$.

b) 流況

対象期間である1990年代において，相模川は年間 平均流量（最下流の長期平均推定值 $32 \mathrm{~m}^{3} \mathrm{~s}^{-1}$ ) の観 点から，大きく分けて平年（1992-93年: $33 \mathrm{~m}^{3} \mathrm{~s}^{-1}$ )，

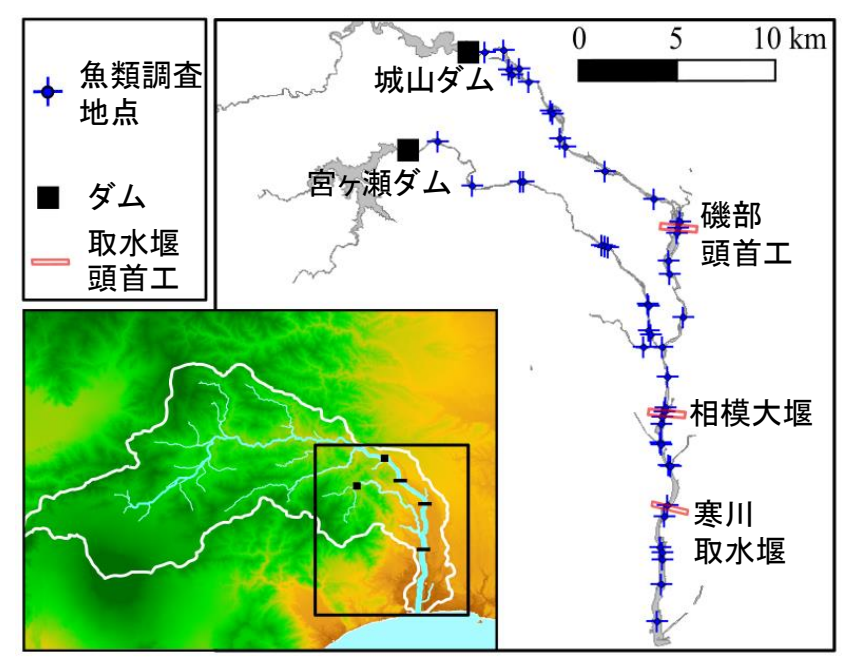

図-1 相模川における対象区域と魚類調査地点

渇水年（1994-96年：22 $\mathrm{m}^{3} \mathrm{~s}^{-1}$ ) ，洪水年（1998-99 年: $\left.60 \mathrm{~m}^{3} \mathrm{~s}^{-1}\right)$ であった. そのため後述の魚類は幅 広い範囲の流況を経験している。区域の本流では, 上端の城山ダムの多目的運用に流況の改変の端を発 しており，中津川との合流までに，複数の取水堰地 点においては, 減水が生じる. 特に顕著な流況改変 として，自然状態に比べ夏場の平時流量が70\%減, 年間最低流量が $80 \%$ 減, 高水の頻度・継続時間の $30 \%$ 減, および低水の30\%長期化 ${ }^{9)}$ が挙げられる. ただし, 中津川からの流入によって, 合流点以下の 流況，特に低水に関しては多少改变が緩和される ${ }^{10)}$. 中津川の流況は，本研究での対象期間1990年代にお いては中津川上端の宮が瀬ダムの運用は開始されて いないことから（2000年4月から），自然流況と仮 定してよい (参考 : 宮が瀬ダム運用開始後の流況改 変はRyo et al. (2015) ${ }^{9)}$ に詳しい)。

\section{（2）対象魚類}

相模川水系魚類調査報告書 ${ }^{8)}$ に記録されている, 魚類種計 20 種の採捕数を用いた. 解析を行うデータ である調査本来の目的は，相模川の魚類生息状況の 把握（種の在不在や構成割合）であり，本研究はそ の調査結果を個体数変動と環境要因の関係性評価に 利用する. 対象地域全体で行われた1993年，1994年， 1997年，1999年を対象とし，秋期（9-11月）におけ る計 45 地点での合計 108 回調査（複数年の地点の重 複あり，それぞれ29,8,35,36回）に基づいた。なお， 各調查は河川縦断方向におおよそ $250 \mathrm{~m}$ (中央值. 河口を除き全て $<500 \mathrm{~m})$ の区間を設け，投網（6，10， $24 \mathrm{~mm}$ ）と電気ショッカー（Smith-Root社製12B）を 用いている. 投網の投打回数は平均23回（6-68回） である。

本研究における個体数とは，調査時において採捕 された総個体数であり，その増減は調査区間に生息 する総個体数の増減を反映すると仮定している．複 数の調査方法（投網回数・電気ショッカーの使用有 無）が用いられ，採捕努力量と採捕数の関係（例え ば，投網回数と採捕数の間に比例を仮定する妥当性 
11)）も明らかでないことから，調査方法自体を説明 変数として含め, 採捕数に及ぼす影響を除いた.

調查全体では40種以上が確認されているが, 個体 数変動の評価に適さないであろう出現頻度が低い (本研究では5回以下) の種は対象外とし, 対象と 寸る魚類種は20種とした. また, 対象魚種は漁協な どにより放流が行われていないことを確認した。

コイ科・八ゼ科が共に7種と支配的であり, 残り はドジョウ科が 2 種, キュウリウオ科・ナマズ科・ ボラ科・カジカ科が1種ずつであった。また, 産卵 期5) は夏の7-9月が最も幅広い種（>8種）にとって 適しており，冬から春にかけて（11-5月）産卵する 種は少ない（図-2）。ほとんどの種の産卵期は，流 量が多く, また高水が発生しや寸い時期である雨季 (6-10月）に対応している.

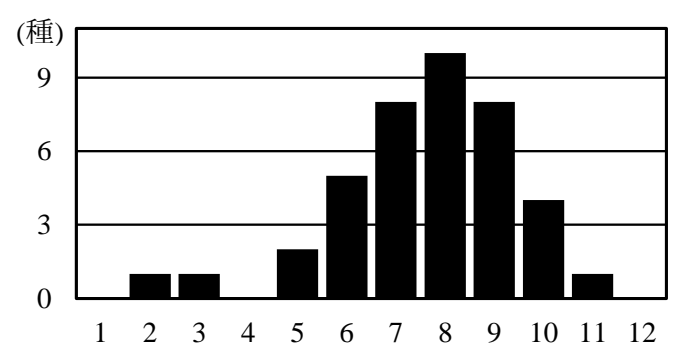

図-2 各月毎の産卵期に該当する種の総数

\section{（3）環境要因}

a)環境要因

年間の魚類の採捕数変動を説明するために，流況， 水温, 水質, 地形状, および調査状況を用いた（解 析に用いた説明変数は表-1）。流況はRyo et al. $(2015)^{9)}$ の流出モデルによる推定值を用い, 月ごと

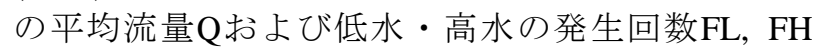
（それぞれ20年分の流量の25th，75th值流量を基準 とし，それらを下回った・上回った回数）を計算し た. 水温 $\mathrm{T}$ と水質項目である $\mathrm{DO}, \mathrm{COD}$ は, 対象区間 において6地点で毎月観測している実測值を用いた

（国土交通省）。なお, 魚類調查地点における水 温・水質項目は, 最近接する観測地点の值とした

（5km以内）。地形状は, 河口からの距離，河床材 の代表粒径, 河床勾配, 相対的最大水深 (河川横断 面における平均標高から最低標高を引いたもの）に 加えて, 調査地点の近傍 $(<500 \mathrm{~m})$ にある地形状の 特徵（堰の上流・下流側か, わんどおよび支流との 合流点の有無）も考慮した. 更に, 魚類調查時の努 力量や環境によっても捕獲量は左右される可能性が あるため, 調查時における電気ショッカー使用の有 無, 投網の投打回数, 水温も考慮した.

b) 環境の時間的区分

季節的に変動する要因（流況, 水温, 水質）に関 しては, 各種魚類の繁殖期に対応させるため, 繁殖 期とその前後の期間（各2か月），およびその他期 間の計4期間に区分した後に, 平均值を計算した

（説明変数にはそれぞれspawn, pre, post, others と区
表-1 解析に用いた説明変数

\begin{tabular}{llll}
\hline 項目 & 変数 & 説明 & 平均値と幅 \\
\hline 流況 & $\mathrm{Q}$ & 平均流量 $\left(\mathrm{m}^{3} \mathrm{~s}^{-1}\right)$ & $19(1.3-179)$ \\
& $\mathrm{FH}$ & 高水発生回数 & $1.3(0-6)$ \\
& $\mathrm{FL}$ & 低水発生回数 & $1.0(0-6)$ \\
水温 & $\mathrm{T}$ & 平均水温 $\left({ }^{\circ} \mathrm{C}\right)$ & $15(2.9-29)$ \\
水質 & DO & 平均溶存酸素量 $\left(\mathrm{mg} \mathrm{L}^{-1}\right)$ & $9.5(4.8-14)$ \\
$\mathrm{COD}$ & 化学的酸素要求量 $\left(\mathrm{mg} \mathrm{L}^{-1}\right)$ & $2.3(0.1-24)$ \\
地形状 distance & 河口からの距離 $(\mathrm{km})$ & $20(0-36)$ \\
& weir_up & 堰の上 & $0 / 1$ \\
weir_down 堰の下 & $0 / 1$ \\
D50 & 河床材代表粒径 $(\mathrm{mm})$ & $54(2-90)$ \\
deepest & 相対的最大水深 $(\mathrm{m})$ & $1.9(0.4-5.4)$ \\
gradient & 河床勾配 $(\%)$ & $0.38(-0.2-1.2$ \\
backwater & 近傍におけるわんどの有無 & $0 / 1$ \\
conf & 近傍における合流点の有無 & $0 / 1$ \\
調查 & elect & 電気ショッカー使用の有無 & $0 / 1$ \\
net & 投網の投打回数 & $23(6-68)$ \\
temp & 調査時水温 $\left({ }^{\circ} \mathrm{C}\right)$ & $16(8-25)$ \\
\hline
\end{tabular}

分）。例えば，ある魚類種の繁殖期が7-9月であれ ば，(1)繁殖期前5-6月，(2)繁殖期，(3)繁殖期後10-11 月，(4)その他12-6月と分け，環境要因はそれぞれの 期間における平均值に区分する。また，環境変動と それに伴う魚類の個体数変動の時間差を考慮するた め, 調查年 $(\mathrm{t})$ に加えその前年 $(\mathrm{t}-1)$ の環境要因 も説明変数とした．時間区分も考慮した場合の説明 変数の総数は60である.

\section{（4）解析手法}

解析にはアンサンブル機械学習法の一つであるラ ンダム・フォレスト ${ }^{12)}$ 用いた。 ランダム・フォレ ス卜は以下の特徵を持ち, 予測精度の向上を目的と した統計解析手法の一つである：(a) サンプルデー 夕母集団の $2 / 3$ のみを使い, 残りは正誤率の検証に 用いる，(b) ブートストラップ法を用いて無数の異 なる回帰木モデルを構築し, 全ての回帰木モデルの 出力の平均值を出力, (c) 回帰木の各分岐点におけ る基準は説明変数から毎回ランダムに選択される. また，このアプローチの利点として，(1)非線形関係 および相互作用を考慮, (2)アンサンブルによる過学 習の回避, (3) $\mathrm{n}<<\mathrm{p}$ 問題に対処（すなわち, 説明変 数の数pがサンプル数nより多い場合は一般的に解析 不可能という問題）がある.

Breimanがランダム・フォレストの基本的概念を

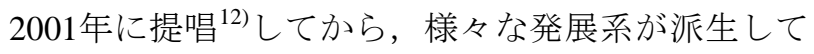
きた。 その中でも，既往の派生形に比べ，「応答変 数に対して重要な説明変数を選択し, 要因を説明す る」という観点で優れている Hapfelmeier and Ulm (2013)のpermutation-based型13)を用いた。特徵として, (1)各変数の効果が統計学的に有意かどうかを判別可 能, (2)偏相関係数に基づく条件付推測により疑似相 関（2つの事象に因果関係はないが，見えない要因 


\section{表-2 複数の魚類種の個体数変動に影響を与え る説明変数}

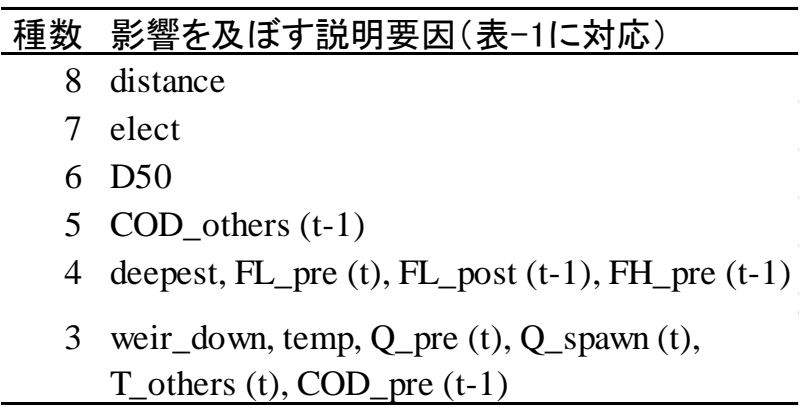

（潜伏変数）を介して相関関係を持つこと）を考慮， (3)欠損值を含むデータも解析可能, といった点が挙 げられる。

本研究では $\mathrm{R}^{14)}$ のpartyパッケージ15)を用いて, 各 魚類種に対し以下の手順で解析を行った。まず，回 帰木モデル数を 500 , 統計的有意性 $(\alpha=0.05)$ を判 別する permutation数を 100 としたランダム・フォレ ストを用いて，各説明変数が有意から゙うかを判別し， 有意でない変数は除外した。次に，精度を高めるた めに回帰木モデル数を 3000 として，有意な変数のみ を用いて解析した. 結果として得られる, 各魚類種 の採捕数の年間変動に対する各説明変数の相対的重 要度（ジ二係数基準）を評価した. また，その他多 くのパラメーターはパッケージの初期設定值のまま とした。

\section{3. 結果と考察}

\section{（1）モデルの当てはまり精度と傾向}

合計20種に対するモデル推定值および実測採捕数

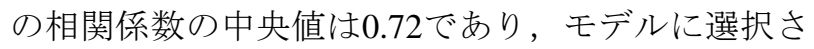
れた有意な説明変数の数は，平均で21個であった. ナマズとオオヨシノボリについては, 有意な変数が 一つも選ばれなかった。

モデルの当てはまりは，相関係数 $>0.7 を$ 考えると 妥当であるが, 有意である説明変数の数は, 一般的 な多変量解析, 特にAIC基準によるべストモデル選 択など，に比べてかなり多い。これは，ランダム・ フォレストは過学習を防ぐ性質を持つが，なるべく 少ない説明変数に㛜選するベストモデル選択の概念 とは本質的に異なり，あくまで予測精度を最大化す ることに重点を置いていること，またアンサンブル を用いることで比較的重要性の低い説明変数すらも 含まれてしまうことに起因する.この傾向は，応答 変数に特に影響を及ぼす説明変数の選択，という観 点からは少し使い勝手が悪い。例えばある変数の影 響が統計的に有意だが $1 \% し か$ 説明力を持たない場 合, それは本研究の目的としては決して重要視され る環境要因ではない, 従って, 本研究では, 選択さ れた各変数の相対的重要度が低いもの（5\%以下） については議論を行わない.

\section{（2）多くの魚類に対して重要な説明要因}

相対的影響度 $>5 \%$ の環境要因で，最も多くの魚種 の採捕数に影響を与えていたものは，地理的要因で ある河口からの距離（distance）と河床材代表粒径 （D50）であった（表-2）。これらは解析上時間的 に一定であるため，それらの空間的な分布が個体数 に影響しているといえ，上流から下流にかけての流 程変位による生息環境の変化が相対的に重要である ことを示唆している．例えば，ワカサギ，ニゴイ， ボラ, マハゼはこれら2つの変数がモデル重要度の 30-50\%を占める. 加えて, 最大水深（4種）および 堰直近下流（3種）も相対的に重要な変数であった。 種によって重要であった変数は異なり，また説明変 数に対する個体数の非線形的な応答もみられたため, 個々の種の結果は詳述しない，ただし一例挙げると， ワカサギ（r=0.61） は，河口から20km以下ではほと んど存在しないがそれより上流に発生し（distance の重要度 $29 \%$ ），かつ水深が $1 \mathrm{~m}$ 以下の浅瀬には存 在せず（deepestの重要性21\%），河床代表粒径が 70-80mm（D50の重要性10\%）以外にはほとんど存 在しない.

年毎に個体数が異なる環境要因としては，流況・ 水温・水質が挙げられる。なお, これらは地理的要 因（例えば河口からの距離）と相関しているが，今 回適用した手法 ${ }^{13)}$ は，そのような説明変数同士の相

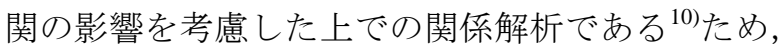
基本的には地点における年変動の影響と考えてよい, 特に複数の種に影響していたのは, 調査前年の繁殖 に関わらない時期の化学的酸素要求量CODであっ た. COD と生物化学的酸素要求量BODは高い相関 をもち（r=0.75-0.91），似た傾向を示した。鬼倉・ 川本 $(2013)^{16)}$ によれば，魚類の生息場選好性はBOD に大きく左右され，本研究対象区域でも酸素要求量 （BODおよび相関の高いCOD）の影響が見られた。 なお，調査時の状況も多くの種の採捕数に影響し ていた。電気ショッカー使用の有無が 18 種中 7 種 （主にコイ科, 表-3）, 調査時の水温が3種に影響 していた一方で，いずれの種でも投網の投打回数は 重要な変数として選ばれなかった．投網の回数が増 えれば増えるほじ採捕数が上昇するとは言えず，逆 に少ない回数でも採捕数が多い場合もあった。これ らは，調查方法によって採捕数が変わることを意味 し,「個体数」推定の困難さを表している ${ }^{11)}$. 例え ば，個体数解析で一般に用いられる，単位努力量あ たりの採捕数だけでは, 個体数を適切な推定を行え ない可能性を示唆している.

\section{（3）流況}

高水・低水発生回数（FH_pre（t-1), FL_pre (t), FL_post (t-1)）が水深と同様に4種に対して影響し た。 それに引き続き, 調査年の産卵期前と中の平均 流量（Q_pre（t), Q_spawn（t)）が3種に影響した（表 $-2)$. 
表-3 魚類各種の個体数変動に及ぼす各環境要因の相対的影響度（\%）。説明変数を表-1の調査項目 にまとめ, 4 つの時期（産卵期前, 産卵期, 産卵期後, その他（各々, 前・期・後 - 他と表記））に 分類した．また各環境項目が影響する総種数，影響する場合の相対的影響度の平均值を算出した。

\begin{tabular}{|c|c|c|c|c|c|c|c|c|c|c|c|c|c|c|c|}
\hline \multirow{2}{*}{ 科 } & \multirow{2}{*}{ 種 } & \multirow{2}{*}{$\begin{array}{c}\text { 地形 } \\
\text { 状 }\end{array}$} & \multirow{2}{*}{$\begin{array}{l}\text { 調査 } \\
\text { 状況 }\end{array}$} & \multicolumn{4}{|c|}{ 流況 } & \multicolumn{4}{|c|}{ 水温 } & \multicolumn{4}{|c|}{ 水質 } \\
\hline & & & & 前 & 期 & 後 & 他 & 前 & 期 & 後 & 他 & 前 & 期 & 後 & 他 \\
\hline コイ & ウグイ & & 10 & 6 & 16 & & & & & & & 15 & & & 7 \\
\hline コイ & アブラハヤ & & 23 & 15 & & 7 & 5 & & & 7 & & & & & \\
\hline コイ & モツゴ & 7 & 8 & 10 & & 8 & & & 12 & 8 & & 5 & & & 6 \\
\hline コイ & カマツカ & 33 & 14 & & & & & & & & 7 & 30 & & & \\
\hline コイ & ニゴイ & 51 & 15 & & & & & & & & 5 & & & & \\
\hline コイ & ギンブナ & 7 & & 7 & 15 & 23 & 7 & & & 9 & & & & & \\
\hline コイ & ゲンゴロウブナ & & & & & 49 & 51 & & & & & & & & \\
\hline ハゼ & シマヨシノボリ & 44 & & & & 9 & 17 & & & & & & & & \\
\hline ハゼ & トウヨシノボリ & 46 & 28 & 7 & 5 & 5 & 6 & & & & & & & 7 & \\
\hline ハゼ & ヌマチチブ & & & 24 & 7 & & & 8 & & & & & & 6 & \\
\hline ハゼ & ウキゴリ & & 9 & 11 & 8 & & 30 & & & 19 & & & & & 6 \\
\hline ハゼ & マハゼ & 7 & & & & & & & & & & & & 15 & 17 \\
\hline ハゼ & ボウズハゼ & & & & & & & 12 & & & & & & & \\
\hline ドジョウ & ドジョウ & & & 59 & & 34 & & & & & & & & & \\
\hline ドジョウ & シマドジョウ & 6 & 6 & 35 & & 20 & 12 & & & & & 8 & & & 8 \\
\hline ボラ & ボラ & & & & & & & & & & & 14 & & 7 & 11 \\
\hline キュウリウオ & ワカサギ & 59 & & & & & 5 & & & & 20 & & & & \\
\hline カジカ & カジカ & 47 & & 8 & 8 & & & & 8 & 30 & & & & & \\
\hline 影響する & 種の総数 & 10 & 8 & 10 & 6 & 8 & 8 & 2 & 2 & 5 & 3 & 5 & 0 & 4 & 6 \\
\hline 影響する場合 & 刀平均重要度(\%) & 31 & 14 & 18 & 10 & 19 & 17 & 10 & 10 & 15 & 11 & 14 & 0 & 9 & 9 \\
\hline
\end{tabular}

時間による区分を全てまとめると，Qに関する総 変数（計8変数）は，20種中8種に影響を示した。ま た高水発生頻度に関しては6種であり，ゲンゴロウ ブナとギンブナ（高水の相対的重要度は $49 \%$ と 29\%）に対して顕著な影響力をもった。低水発生頻 度は10種に影響し，特にドジョウは調査前年の渴水 頻度の相対的重要度が93\%と非常に高い（低水発生 が多いほど個体数が多い，ただし最大採捕数は3匹 と，值は低い）。

未だ流況と個々の種の関係の多くは未解明であり, これらのような推察は, 今後の河川魚類生態の理解 に役立つ. 平均流量と比べても, 高水・低水発生頻 度の影響度は遜色がないほどの種数に対して重要な 環境要因であった。例えばギンブナは，調查前年の 産卵期7-8月に高水が2回以上発生した場合には，採 捕数が少ない傾向が示唆された. 現在, 河川管理上 においても, 高水発生の生態学的重要性は認知され てきている（相模川でも人為的な小規模出水の影響 試験が実施されている）が，その頻度や時期に関し ても，生息する生物の生活史の周期性を考慮する必 要があると言えよう。

ただし，相対的重要度 $5 \%$ 以下も含めると（未掲 載），多くの種に影響を及ぼす環境要因の上位4-8 位は全て流量 $\mathrm{Q} の$ 変数で占められ（上位1-3位の変 数はdistance, D50, electで変わらず），18種中15種に おいて統計的に有意であった。 従って, 平均流量は 多くの種にとって幅広く影響する要因であることに
は変わりない.

\section{（4）時間的区分：繁殖期とその前後の環境}

各環境要因（表-1）が個体数の変動に及ぼす相対 的影響度は，時期によって，また種によっても異 なった（表-3）。例えば，八ゼ科ボウズ八ゼの個体 数変動は, 産卵期前の水温のみに影響される (12\%）。これは，産卵期前の水温の年ごとの変動 (相対的に高いか低いか) と，ボウズハゼの個体数 の年ごとの変動（相対的に多いか少ないか）が統計 的に有意に相関していることを示している．一方で, 産卵期前以外の時期の水温や，その他環境要因の年 ごとの変動は個体数の変動と統計的には有意な関係 がないと判断される.

各環境要因・各時期が影響する種の総数や, 影響 する場合の平均的な影響度を考慮し（表-3）, 総合 的に流況 - 水温 - 水質の時期の重要性を一般化する と，興味深いことに，産卵期中の環境要因は比較的 重要ではなく，むしろ産卵期の前後の時期において 影響度が高いという結果になった。流況は概してど の時期も水質や水温と比べて多くの種に影響し，ま た相対的な影響度も高い傾向にあった（表-3）。最 も多くの種に影響していたのは産卵期前の流況（10 種）であった。 また，産卵期後の流況が影響する場 合（8種）にはもつとも相対的重要度が高く （19\%），その影響度は産卵期（10\%）の倍となっ た。産卵期前後はそれぞれ，産卵環境の更新や，仔 
稚魚の生存率に関係しているものと思われる。また， 水温と水質は比較的明確な時期傾向を示し, 水温は 産卵期後が5種に $15 \%$ の相対影響度を持って影響し， 産卵期前の水質がほぼ同等の影響度（5種，14\%） であった，その他の時期においては影響する種の総 数・相対影響度がやや低い傾向にあった。

\section{4. 結論と今後の展望}

本研究は, 複数年にまたがる個体数変動および繁 殖時期に焦点を当てた解析を行った。従来の在・不 在や生息場好適性の解析に加え, 河川魚類の生態と 環境要因を異なる観点から評価した。また多くの既 往研究では, 環境要因の季節性を考慮して生態系と 関連付ける際に, 気候的な季節性（気温・降雨量な ど）に基づく区分が多いが，本研究では，個体数に 影響を及ぼす要因のうち, 比較的時期が既知である 産卵期を基点とした季節区分を行った。時期の違い によって環境要因が魚類の個体数に与える影響度は 異なり, 今回解析対象とした 20 種を総合的に評価す ると, 産卵期前（相模川ではおおよそ4-6月, 図一 2）の流況および産卵期後（10-12月，図-2）の流況 と水温が特に重要であることが分かった。

河川管理上において, 地形状や水質に比べて流況 はダム放流などにより操作がしやすい，それゆえ流 況保全の観点に基づいたダム下流生態系の管理が期 待される. しかし, どのように流況操作を行うべき かは, 依然議論の余地がある. 本研究が示唆したよ うに, 高水の発生頻度は魚類の個体数とも関係して おり, 更にその発生時期によって影響度・影響され る種は異なるため, 人為的な高水出水の影響評価に は魚類の個体数も加味すべきである.

現在, 河川生物のモデルは統計的な関係の記述 （線形回帰など）から，より一層生態プロセスに基 づいたモデルへと移行しつつある゙). そのためには 行動や死亡に関わる詳細なパラメーター, 寸なわち 環境要因と生物生活史に関連した関係性の知見の蓄 積が必要である. 従って, 実河川における長期の動 態を, まずは統計から段階的に明らかにしてゆくこ とが望まれる.

\section{謝辞}

データ提供をして下さった神奈川県庁および神奈川 県水産技術センター内水面試験場に感謝の意をここ に表します.また, 多くの有益な意見を下さった森 照貴氏に感謝します。この研究は, JST CREST, JSPS特別研究員制度（26_11771），JSPS科研費 （15K00592）による支援を受けました。

\section{参考文献}

1) World Wide Fund for Nature: Living Planet Report 2014, 2014.

2）高瀬陽彦，糠澤桂，風閒聡，渡辺幸三，分布型水文 モデルと確率密度関数を用いた底生動物の生息環境 および種多様性評価, 土木学会論文集B1（水工学）, Vol.70, No.4, pp.I_1297-I_1302, 2014.

3) Beechie, T. J., Sear D. A., Olden J. D., Pess G. R., Buffington J. M., Moir H., Roni P. and Pollock M. M.: Process-based Principles for Restoring River Ecosystems, Bioscience, Vol. 60, No. 3, pp. 209-222, 2010.

4) Mims, M. C. and Olden J. D.: Life history theory predicts fish assemblage response to hydrologic regimes, Ecology, Vol. 93, No. 1, pp. 35-45, 2012.

5) 川那部 浩哉, 水野 信彦, 日本の淡水魚（山渓カラー 名鑑改訂版)，山と溪谷社，pp. 719, 2001.

6) Poff, N. L., Allan D. J., Bain B. B., Karr J. J. R., Prestegaard K. L., Richter B. D., Sparks R. E. and Stromberg J. C.: The natural flow regime, Bioscience, Vol. 47, No. 11, pp. 769-784, 1997.

7) Poff, N. L., Richter B. D., Arthington A. H., Bunn S. E., and 15 others: The ecological limits of hydrologic alteration (ELOHA): a new framework for developing regional environmental flow standards, Freshw. Biol., Vol. 55, No. 1, pp. 147-170, 2010.

8）相模川水系魚類生息状況調查報告書, 神奈川県水産 総合研究所 内水面試験場.

9) Ryo, M., Iwasaki Y., Yoshimura C. and Saavedra O. C. V.: Evaluation of Spatial Pattern of Altered Flow Regimes on a River Network Using a Distributed Hydrological Model, PLoS One, Vol. 10, No. 7, pp. 1-16, 2015.

10) Ryo, M., Yoshimura C., Saavedra O. C. V., and Sui P.: Longitudinal trends of flow regimes altered by dams in the lowland section of Sagami River, Annu. J. Hydraul. Eng., Vol. 58, 2014.

11) McCluskey S.M. and Lewison R.L.: Quantifying fishing effort: a synthesis of current methods and their applications, Fish and Fisheries, Vol. 9, pp.188-200, 2008.

12) Breiman, L.: Random Forests, Mach. Learn., Vol. 45, pp. 5-32, 2001.

13) Hapfelmeier, A. and Ulm K.: A new variable selection approach using Random Forests, Comput. Stat. Data Anal., Vol. 60, pp. 50-69, 2013.

14) $\mathrm{R}$ Core Team, R: A Language and Environment for Statistical Computing, $R$ Foundation for Statistical Computing, Vienna, Austria, 2014

15) Strobl, C., Hothorn T. and Zeileis A.: Party on! A new, Conditional Variable-Importance Measure for Random Forests, $R$ J., Vol. 1, No. 2, pp. 14-17, 2009.

16) 鬼倉 徳雄, 川本 朋慶 : 九州北部の一級水系にお ける水質と純淡水魚類の出現との関係, 水環境学会 誌, Vol. 36, No. 3, pp. 99-106, 2013.

(2015. 9. 30受付) 